\title{
Study of Prevalence of Hepatitis B, Hepatitis C, and Other Opportunistic Coinfections in HIV-infected Patients in a Tertiary Care Hospital of North India
}

\author{
Deepinder Chhina ${ }^{1}$, Shikha Garg ${ }^{2}$, Rajoo Chinna ${ }^{3}$, Pulkit Dhiman ${ }^{4}$, Divyani Gupta ${ }^{5}$
}

\begin{abstract}
Background and objectives: There is only limited information on the prevalence of coinfection with hepatitis B virus (HBV) and hepatitis $C$ virus (HCV) in human immunodeficiency virus (HIV)-infected individuals, resulting in greater morbidity and mortality. This study was done to evaluate the prevalence of HBV and HCV in HIV-infected individuals attending a tertiary care hospital in north India.

Materials and methods: A total of 104 HIV patients were included in this study of 6-month duration (January-June 2019). Samples were tested for hepatitis B surface antigen ( $\mathrm{HBsAg}$ ) and anti-HCV antibodies by rapid detection method and/or enzyme-linked immunosorbent assay (ELISA). $\mathrm{HBsAg}$ positive serum samples and anti-HCV positive samples were further tested for HBV-DNA and HCV-RNA, respectively. Other opportunistic infections were studied along with it.

Results: Among the 104 HIV-positive patients, 11 (10.6\%) were anti-HCV positive and 7 of 11 (63.6\%) were positive for HCV-RNA. Three (2.8\%) suffered from chronic HBV coinfection (HBsAg positive) and 2 of $3(66.7 \%)$ were positive for HBV-DNA. Triple infection with HBV, HCV, and HIV was seen in $0.9 \%$ of patients. The most common mode of transmission was sexual promiscuity (76\%), followed by infected needle/unknown (13.5\%), and a history of intravenous drug abuse (10.5\%). The demographic distribution shows the maximum number of patients (38.5\%) belonging to the Ludhiana district of Punjab.

Interpretation and conclusions: The findings show a prevalence of 10.6 and $2.8 \%$ for HCV and HBV, respectively, in HIV-positive patients. Coinfection with HCV-HIV is more frequent than HBV-HIV. Hence, all HIV patients need to be routinely tested for markers of HBV and HCV.

Keywords: Coinfection, Hepatitis B virus, Hepatitis C virus, Human immunodeficiency virus, Opportunistic infections.

Journal of Gastrointestinal Infections (2020): 10.5005/jp-journals-10068-3043
\end{abstract}

\section{INTRODUCTION}

Human immunodeficiency virus (HIV), hepatitis B virus (HBV), and hepatitis $C$ virus ( $\mathrm{HCV}$ ) coinfection has emerged as a leading cause of morbidity due to liver disease throughout the world in the last two decades. ${ }^{1,2}$ Among the HIV-infected patients, HBV and HCV coinfections are more prevalent due to common transmission routes. ${ }^{3}$ HIV-induced impairment of the cell-mediated immunity causes a higher replication of hepatotropic viruses.

HIV infection modifies the natural history of chronic parenterally acquired hepatitis $C$ with unusually rapid progression to cirrhosis, hepatocellular carcinoma, and liver failure. ${ }^{4,5}$ Overall survival of HIVpositive patients is not affected by the presence of HCV; however, earlier reports suggest that coinfection of HIV with either HCV or HBV accelerates the clinical course of HIV-infected patients. ${ }^{6}$ People living with HIV are less likely to naturally clear HCV infection. They also tend to have more aggressive liver disease progression. HIV infection increases the levels of HCV viremia by 2-8-fold, resulting in a significant decrease in spontaneous recovery of acute hepatitis. HIV coinfection also worsens the histological course of $\mathrm{HCV}$ infection by increasing and accelerating the risk of cirrhosis or leading to rare but lethal fibrosing cholestatic hepatitis. ${ }^{6}$

The importance of comorbidities, such as chronic liver disease due to HBV and HCV infections, is being recognized as significant problems. Most of the studies ${ }^{6,7,8}$ on HIV-HBV and HIV-HCV coinfected patients have been conducted in Western countries. Understanding HBV and HCV coinfections with HIV is particularly important in Asian countries due to the high background prevalence
1,2,5 Department of Microbiology, Dayanand Medical College and Hospital, Ludhiana, Punjab, India

${ }^{3,4}$ Department of Gastroenterology, Dayanand Medical College and Hospital, Ludhiana, Punjab, India

Corresponding Author: Shikha Garg, Department of Microbiology, Dayanand Medical College and Hospital, Ludhiana, Punjab, India, Phone: +91 9814915466, e-mail: docshikhagarg@gmail.com

How to cite this article: Chhina D, Garg S, Chinna R, et al. Study of Prevalence of Hepatitis B, Hepatitis C, and Other Opportunistic Coinfections in HIV-infected Patients in a Tertiary Care Hospital of North India. J Gastrointest Infect 2020;10(1):7-10.

Source of support: Departmental funds

Conflict of interest: None

of HBV and HCV. ${ }^{9}$ In this study, we investigated the prevalence of HBV and HCV infections in patients with HIV infection and their route of transmission and demographic areas of higher prevalence.

\section{Materials and Methods}

This retrospective observational study was carried out in the Department of Microbiology, Dayanand Medical College and Hospital, Ludhiana, for a period of 6 months (January-June 2019). This study has been approved by the institutional ethics committee.

The study included 104 diagnosed HIV patients. The record of patients including name, age, gender, residential area, and a

(0) Jaypee Brothers Medical Publishers. 2021 Open Access This article is distributed under the terms of the Creative Commons Attribution 4.0 International License (https://creativecommons.org/licenses/by-nc/4.0/), which permits unrestricted use, distribution, and non-commercial reproduction in any medium, provided you give appropriate credit to the original author(s) and the source, provide a link to the Creative Commons license, and indicate ifchanges were made. The Creative Commons Public Domain Dedication waiver (http://creativecommons.org/publicdomain/zero/1.0/) applies to the data made available in this article, unless otherwise stated. 
detailed history of sexual activities, blood transfusion, intravenous drug abuse, and treatment from a local practitioner if any and other opportunistic infections was obtained.

HIV-infected patient samples were also tested for HBsAg and anti-HCV antibodies (Diagnostic Enterprise, Himachal Pradesh, India) rapid detection method and/or by enzyme-linked immunosorbent assay (ELISA) (Cobas, Roche Diagnostics, Mumbai, India and Gmbh, Germany) as per the manufacturer's instructions.

$\mathrm{HBsAg}$-positive serum samples were further tested for HBVDNA. Anti-HCV positive samples were tested further for HCVRNA. Qualitative HBV-DNA and HCV-RNA were tested using the polymerase chain reaction (PCR) technique in all $\mathrm{HBsAg}$ and anti-HCV positive patients, respectively. HBV-DNA and HCV-RNA were detected using automated Real time PCR system, the COBAS AmpliPrep-COBAS TaqMan (CAP-CTM; Roche Diagnostics, USA). It is nucleic acid amplification test for the quantitation of HBV-DNA and HCV-RNA in infected individuals. HBV DNA testing provides security in results due to high specificity and accuracy, using primers and probes targeting the highly conserved pre-core and core region. HCV-RNA are based on three major processes: (1) specimen preparation to isolate HCV RNA; (2) reverse transcription of the target RNA to generate complementary DNA (CDNA) and (3) simultaneous PCR amplification of target CDNA and detection of cleaved dual-labeled oligonucleotide detection probe specific to the target.

Other opportunistic infections like tuberculosis were studied either using Ziehl Neelsen (ZN) staining/Auramine staining and/ or Line Probe Assay in clinically suspected patients. Cryptococcus neoformans causing central nervous system (CNS) infection was studied using India Ink and/or cryptococcal antigen detection. Cryptosporidium parvum was studied using modified ZN staining and/or cryptosporidium antigen in clinically suspected patients. Other infections like the presence of Herpes IgG antibodies were studied on CHORUS and scrub typhus using ELISA.

\section{Statistical Analysis}

Statistical analysis was done using the Chi-square test and $p$-values were obtained.

\section{Results}

Among the 104 HIV-positive patients studied, 22 (21.15\%) patients were female and 82 (78.8\%) patients were male. The male to female ratio was 3.7:1. The distribution of patients with respect to age and gender is mentioned in Table 1.
Coinfection of HIV with HCV was seen in 11 (10.6\%) of 104 patients and 7 of 11 (63.6\%) of these sera were positive for HCV-RNA on further testing. Three out of 104 patients (2.8\%) were positive for HBV coinfection (HBsAg positive), two-thirds of the sera $(66.7 \%)$ had positive HBV-DNA. Triple infection with HBV, $\mathrm{HCV}$, and $\mathrm{HIV}$ was seen in 1 patient $(0.9 \%)$.

The most common mode of transmission was sexual promiscuity (76\%), followed by infected needles/unknown (13.5\%) and a history of intravenous (I/V) drug abusers (10.5\%). $\mathrm{I} / \mathrm{V}$ drug abuse was prevalent in young adults in the age group of 18 to 30 years and sexual transmission was prevalent in 41 to 60 years. The patients who came with a history of use of infected needles or are of unknown source status were usually elderly from remote areas. The difference between these parameters (Tables 2 and 3 ) was found to be statistically significant ( $p$-value $\leq$ 0.00).

Geographical/demographic distribution shows the maximum number of patients who were HIV-positive belonged to Ludhiana district (38.5\%) followed by Hoshiarpur district of Punjab and a few cases from adjoining states like Jammu, Delhi, Uttar Pradesh, and Himachal Pradesh (Fig. 1).

Other opportunistic infections like tuberculosis were observed in 3 patients and 1 patient had coinfection with $C$. neoformans. $C$. parvum was observed in the stool sample of 1 patient who was HIV-positive (Table 4).

Table 1: Distribution of HIV-positive patients with age and gender $(n=104)$

\begin{tabular}{llrrrr}
\hline & \multicolumn{2}{c}{ Gender } & & & \\
\cline { 2 - 3 } $\begin{array}{l}\text { Age group } \\
\text { (in years) }\end{array}$ & $\begin{array}{l}\text { Female } \\
n(\%)\end{array}$ & $\begin{array}{l}\text { Male } \\
n(\%)\end{array}$ & \multicolumn{1}{l}{$\begin{array}{l}\text { Total } \\
n(\%)\end{array}$} & $\begin{array}{l}\text { Chi-square } \\
\text { value }\end{array}$ & \\
\hline $10-20$ & $1(4.5)$ & $3(0.0)$ & $4(3.8)$ & & \\
$21-30$ & $4(18.2)$ & $13(0.0)$ & $17(16.3)$ & & \\
$31-40$ & $5(22.7)$ & $15(0.0)$ & $20(19.2)$ & & \\
$41-50$ & $5(22.7)$ & $22(0.0)$ & $27(26.0)$ & 3.895 & 0.691 \\
$51-60$ & $5(22.7)$ & $17(0.0)$ & $22(21.2)$ & & \\
$61-70$ & $0(0.0)$ & $9(0.0)$ & $9(8.7)$ & & \\
$71-120$ & $2(9.1)$ & $3(0.0)$ & $5(4.8)$ & & \\
Total & $\mathbf{2 2 ( 1 0 0 )}$ & $\mathbf{8 2 ( 0 . 0 )}$ & $\mathbf{1 0 4 ( 1 0 0 )}$ & & \\
\hline
\end{tabular}

Table 2: Distribution and comparison of HIV patients in relation to the route of transmission and age

\begin{tabular}{|c|c|c|c|c|c|c|}
\hline \multirow[b]{2}{*}{$\begin{array}{l}\text { Age group } \\
\text { (in years) }\end{array}$} & \multicolumn{3}{|c|}{ Route of transmission } & \multirow[b]{2}{*}{$\begin{array}{l}\text { Total } \\
n(\%)\end{array}$} & \multirow[b]{2}{*}{ Chi-square value } & \multirow[b]{2}{*}{$p$-value } \\
\hline & $\begin{array}{l}I / V \\
n(\%)\end{array}$ & $\begin{array}{l}\text { Sexual } \\
n(\%)\end{array}$ & $\begin{array}{l}\text { Unknown/infected needle } \\
n(\%)\end{array}$ & & & \\
\hline $10-20$ & $3(27.3)$ & $1(1.3)$ & $0(0.0)$ & $4(3.8)$ & \multirow{8}{*}{50.826} & \multirow{8}{*}{0.000} \\
\hline $21-30$ & $3(27.3)$ & $14(17.7)$ & $0(0.0)$ & $17(16.3)$ & & \\
\hline $31-40$ & $2(18.2)$ & $17(21.5)$ & $1(7.1)$ & $20(19.2)$ & & \\
\hline $41-50$ & $2(18.2)$ & $22(27.8)$ & $3(21.4)$ & $27(26.0)$ & & \\
\hline $51-60$ & $1(9.1)$ & $19(24.1)$ & $2(14.3)$ & $22(21.2)$ & & \\
\hline $61-70$ & $0(0.0)$ & $5(6.3)$ & $4(28.6)$ & $9(8.7)$ & & \\
\hline $71-120$ & $0(0.0)$ & $1(1.3)$ & $4(28.6)$ & $5(4.8)$ & & \\
\hline Total & $11(100)$ & $79(100)$ & $14(100)$ & $104(100)$ & & \\
\hline
\end{tabular}


HIV-positive, Hepatitis B, and Hepatitis C Opportunistic Infections

Table 3: Distribution and comparison of HIV patients in relation to the route of transmission and gender

\begin{tabular}{|c|c|c|c|c|c|c|}
\hline \multirow[b]{2}{*}{ Gender } & \multicolumn{3}{|c|}{ Route of transmission } & \multirow[b]{2}{*}{$\begin{array}{l}\text { Total } \\
n(\%)\end{array}$} & \multirow[b]{2}{*}{ Chi-square value } & \multirow[b]{2}{*}{$p$-value } \\
\hline & $\begin{array}{l}I / N \\
n(\%)\end{array}$ & $\begin{array}{l}\text { Sexual } \\
n(\%)\end{array}$ & $\begin{array}{l}\text { Unknown/infected needle } \\
n(\%)\end{array}$ & & & \\
\hline Female & $0(0.0)$ & $18(22.8)$ & $4(28.6)$ & $22(21.2)$ & & \\
\hline Male & $11(100)$ & $61(77.2)$ & 10 (71.4) & $82(78.8)$ & 3.539 & 0.170 \\
\hline Total & $11(100)$ & $79(100)$ & $14(100)$ & $104(100)$ & & \\
\hline
\end{tabular}

Table 4: Distribution of HIV-positive patients coinfected with other opportunistic infections

\begin{tabular}{|c|c|c|}
\hline $\begin{array}{l}\text { Other opportunistic } \\
\text { infections }\end{array}$ & $\begin{array}{l}\text { No. of } \\
\text { patients }\end{array}$ & Method of detection/diagnosis \\
\hline Tuberculosis & 3 & ZN/Auramine/Line Probe Assay \\
\hline Cryptococcus & 1 & Cryptococcal Antigen/India Ink \\
\hline Cryptosporidium parvum & 1 & $\begin{array}{l}\text { Cryptosporidium Antigen/ } \\
\text { Modified ZN }\end{array}$ \\
\hline HERPES IgG positive & 1 & CHORUS \\
\hline Scrub typhus positive & 1 & ELISA \\
\hline Anti-HAV Positive & 1 & ELISA \\
\hline
\end{tabular}

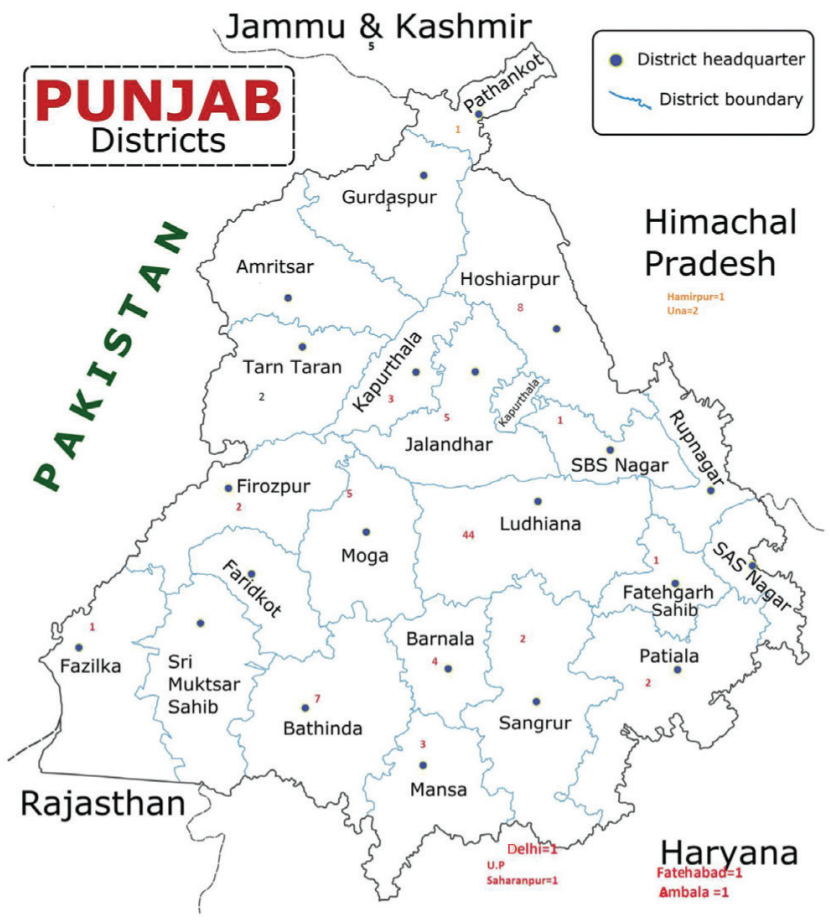

Fig. 1: Geographical distribution of HIV-positive cases in Punjab state (number represents cases)

\section{Discussion}

As per Joint United Nations Programme on HIV/AIDS (UNAIDS) estimates, in 2016, with an adult HIV prevalence of $0.8 \%$ and considerable variation between countries, 36.7 million (30.8-42.9 million) people were estimated to be living with HIV globally. India has a low HIV prevalence of $0.22 \%$. The country's endemic is concentrated among high-risk groups and is heterogeneously distributed with wide geographic variations in the vulnerabilities that drive the epidemic. Even with this low prevalence, in terms of absolute numbers, India has the third highest burden of HIV in the world with an estimated 2.14 million people living with HIV, 87,000 estimated new infections, and 69,000 AIDSrelated deaths annually. The first few cases of HIV in the country were detected among female sex workers in Chennai, Tamil Nadu, in 1986, followed by reports from other parts of the country. ${ }^{10}$

Coinfections of HIV patients with HBV and HCV are major public health problems, contributing to the emerging burden of HIVassociated hepatic mortality. Chronic viral hepatitis has emerged as an important cause of morbidity and mortality among HIV-positive patients resulting in an increase in inpatient healthcare utilization and an evolving discussion on the use of liver transplantation in these patients. ${ }^{11}$

The prevalence of HBV and HCV coinfections in HIV has been variably reported in different studies. ${ }^{12-15}$ The prevalence of HBV varies markedly among different HIV-infected population and geographical location is one of the major determinants of prevalence. The prevalence of HBV coinfection varies from 5 to $7 \%$ in low endemic areas. In intermediate and high endemic areas, it varies from 6 to $20 \%$. The prevalence of HCV coinfection varies from 9 to $16 \%$. About $10 \%$ of people living with HIV in the United Kingdom also have hepatitis C. This is much more common in certain groups, such as people who inject themselves with drugs.

We found HBV coinfection in $2.8 \%$ of HIV-positive individuals. The HCV coinfection in the present study was $10.6 \%$. The HCV coinfection was higher in our study compared to $1.6 \%$ in Lucknow ${ }^{16}$, $7.2 \%$ in Nagpur ${ }^{17}$, and $2.3 \%$ in Chennai. ${ }^{18}$ The route of transmission of HIV in most of our patients was sexual contact. Geographical/ demographic distribution shows the maximum number of patients (38.5\%) belonging to Ludhiana district followed by Hoshiarpur district of Punjab.

\section{Conclusion}

It is evident from the present study that the HIV-infected patients in this region have a high risk of acquiring HBV/HCV coinfections through the shared routes of transmission. Hence, HIV patients should routinely be tested for HBV and HCV markers. HBV coinfection does not appear to influence the rate of HIV progression but may be a surrogate for factors associated with HIV seroconversion. Patients receiving HIV treatment should receive fully active $\mathrm{HBV}$ treatment as well, avoiding lamivudine (3TC) or emtricitabine (FTC) monotherapy. Screening the high-risk population for these infections would aid in prompt diagnosis and treatment with improved outcomes in these patients. 


\section{References}

1. Rockstroh JK. Influence of viral hepatitis on HIV infection. J Hepatol 2006;44:525-527. DOI: 10.1016/j.jhep.2005.11.007.

2. Duming JRG, Nelson M. HIV and hepatitis with co-infection. Int J Clin Pract 2005;59:1082-1092.

3. Alter MJ. Epidemiology of viral hepatitis and HIV co-infection. J Hepatol 2006;44(Suppl 1):S6-S9. DOI: 10.1016/j.jhep.2005.11.004.

4. Mocroft A, Monforte A, Kirk O, et al. Decline in AIDS and death rates in EuroSIDA study: an observational study. Lancet 2003;362(9377):22-29. DOI: 10.1016/s0140-6736(03)13802-0.

5. Soto B, Sanchez Quijano A, Rodrigo L, et al. Human immunodeficiency virus infection modifies the natural history of chronic parentallyacquired hepatitis $C$ with an unusually rapid progression to cirrhosis. J Hepatol 1997;26(1):1-5. DOI: 10.1016/s0168-8278(97)80001-3.

6. Vallet-Pichard A, Pol S. Natural history and predictors of severity of chronic hepatitis $\mathrm{C}$ virus (HCV) and human immunodeficiency virus (HIV) co-infection. J Hepatol 2006;44(Suppl 1):S28-S34. DOI: 10.1016/j. jhep.2005.11.008.

7. Konopnicky D. Hepatitis B and HIV: prevalence, AIDS progression, response to highly active antiretroviral therapy and increased mortality in the EuroSIDA cohort. AIDS 2005;19(6):593-601. DOI: 10.1097/01.aids.0000163936.99401.fe.

8. Amin J, Kaye M, Skidmore $S$, et al. HIV and hepatitis $C$ coinfection within the CAESAR study. HIV Med 2004;5(3):174-179. DOI: 10.1111/j.1468-1293.2004.00207.x.

9. Hoffmann CJ, Thio CL. Clinical implications of HIV and hepatitis B co-infection in Asia and Africa. Lancet Infect Dis 2007;7(6):402-409. DOI: 10.1016/S1473-3099(07)70135-4.
10. National Technical Guidelines On Anti Retroviral Treatment October, 2018.

11. Weitzel T, Rodríguez F, Noriega LM, et al. Hepatitis $B$ and $C$ virus infection among HIV patients within the public and private healthcare systems in Chile: a cross-sectional serosurvey. PLoS One 2020;15(1):e0227776. DOI: 10.1371/journal.pone.0227776.

12. Pratt DS, Kaplan MM, Longo DI, et al. Evaluation of liver function. In: Harrison's Principles of Internal Medicine. New York: McGraw Hill; 2012. pp. 2527-2530.

13. Thio CL, Seaberg EC, Skolasky R, et al. HIV-1, hepatitis B virus, and risk of liver-related mortality in the multicenter cohort study (MACS). Lancet 2002;360(9349):1921-1926. DOI: 10.1016/s0140-6736(02)11913-1.

14. Thio $C L$. Hepatitis $B$ and human immunodeficiency virus coinfection. Hepatology 2009;49(5 Suppl):S138-S145. DOI: 10.1002/hep.22883.

15. Tedaldi EM, Hullsick KH, Malvestutto CD, et al. Prevalence and characteristics of hepatitis $C$ virus coinfection in a human immunodeficiency virus clinical trials groups: The Terry Beirn Community Programs for Clinical Research on AIDS. Clin Infect Dis 2003;36(10):1313-1317. DOI: 10.1086/374841.

16. Tripathi AK, Khanna M, Gupta N, et al. Low prevalence of hepatitis $B$ virus and hepatitis $C$ virus coinfection in patients with human immunodeficiency virus in Northern India. J Assoc Physicians India 2007;55:429-431.

17. Tankhiwale SS, Khadase RK, Jalgaonkar SV. Seroprevalence of anti$\mathrm{HCV}$ and hepatitis B surface antigen in HIV infected patients. Indian J Med Microbiol 2003;21(4):268-270.

18. Sarvanan S, Velu V, Kumarswamy N, et al. Co-infection of hepatitis B and hepatitis C virus in HIV-infected patients in south India. World J Gastroenterol 2007;13(37):5015-5020. DOI: 10.3748/wjg.v13.i37.5015. 